\title{
Melacak keberadaan ideologi pada film Cahaya dari Timur: Beta Maluku
}

\author{
Laksmi Rachmaria \\ Universitas Budi Luhur, Jakarta, Indonesia
}

\begin{abstract}
ABSTRAK
Posisi Indonesia sebagai negara multikultur membuatnya rentan terhadap ancaman separatisme dan konflik komunal berbasis suku, agama, dan antargolongan. Maluku merupakan sebuah tempat di mana pernah terjadi tragedi kemanusiaan terbesar dalam sejarah bangsa Indonesia. Tak hanya merenggut korban dari kalangan laki-laki dewasa, konflik komunal ini juga merenggut masa depan anak-anak yang berada di tengah-tengah kelompok yang bertikai. Penelitian ini bertujuan untuk melihat bagaimana wacana resiliensi ditampilkan pada film Cahaya dari Timur: Beta Maluku. Penelitian ini menggunakan pendekatan kualitatif dengan metode analisis wacana kritis Norman Fairclough. Analisis wacana kritis merupakan salah satu cara untuk membongkar adanya sebuah ketidakberesan di masyarakat. Film ini merupakan sebuah film drama yang diangkat dari kisah nyata tentang bagaimana sepak bola dapat mengobati jiwa anak-anak yang terluka akibat konflik komunal yang terjadi di Maluku. Teks merupakan sebuah situs perjuangan sosial yang berusaha mencairkan dan melacak keberadaan ideologi. Menganalisis wacana secara kritis pada hakikatnya adalah menganalisis tiga dimensi wacana secara integral, yakni taks-teks bahasa, praksis kewacanaan, dan praksis sosiokultural. Hasil penelitian: pada level teks film Cahaya dari Timur: Beta Maluku menggambarkan bagaimana kondisi anak-anak korban konflik komunal Maluku untuk bangkit dari keterpurukan, berjuang mengobati luka batin akibat konflik komunal. Pada level praksis kewacanaan menekankan tentang kegagalan pemerintah dalam melakukan rehabilitasi sosial masyarakat. Level sosiokultural masyarakat sesungguhnya merupakan korban dari politisasi agama. Ideologi Pela-Gandong merupakan kultur khas Maluku sebagai sarana penyelesaian konflik komunal.
\end{abstract}

Kata-kata Kunci: Teks; ideologi; film; wacana; konflik komunal

\section{Tracing ideology in Cahaya dari Timur: Beta Maluku film}

\begin{abstract}
Indonesia's position as a multicultural country makes it vulnerable to the threat of separatism and communal conflicts based on ethnicity, religion, and between groups. Maluku is a place where the greatest human tragedy occurred in the history of the Indonesian nation. Not only did this communal conflict claim the future of the children who were in the midst of warring groups. This study aims to see how the discourse of resilience is shown in Cahaya dari Timur Beta Maluku film. This study uses a qualitative approach with Norman Fairclough's critical discourse analysis method. Critical discourse analysis is one way to uncover an irregularity in society. This film is a drama film based on a true story about how football can heal the souls of children who have been injured due to the communal conflict that occurred in Maluku. Text is a social struggle site that tries to dilute and trace the existence of ideology. Analyzing discourse critically is essentially analyzing three dimensions of discourse integrally, namely language text taxis, discourse praxis, and sociocultural praxis. The results of the study: at the text level of Cahaya dari Timur Beta Maluku film, it describes how the condition of child victims of the Maluku communal conflict to rise from adversity, struggling to heal the emotional wounds caused by communal conflicts. At the level of discourse praxis emphasizes the failure of the government to carry out social rehabilitation for the community. The sociocultural level of society is actually a victim of the politicization of religion. The Pela-Gandong ideology is a typical Maluku culture as a means of resolving communal conflicts.
\end{abstract}

Keywords: Text; ideology; discourse; film; communal conflict

Korespondensi: Laksmi Rachmaria, S.Sos., M.I.Kom. Universitas Budi Luhur. Jalan Raya Petukangan Utara, Ciledug, Jakarta Selatan Kode Pos 12260.Email: laksmi.ozil@gmail.com 


\section{PENDAHULUAN}

Indonesia merupakan negara majemuk dalam berbagai hal, agama, keyakinan, ras, maupun suku bangsa. Ibarat sebuah mata uang, kondisi ini di satu sisi memiliki potensi yang menguntungkan, akan tetapi di sisi lain dapat juga memberikan ancaman bagi persatuan dan kesatuan bangsa. Potensi kemajemukan bisa bermakna positif, bahwa dengan keberagaman keyakinan yang ada merupakan sumber nilai local wisdom bagi keutuhan bangsa ini. Akan tetapi keragaman keyakinan warganya di sisi lain ternyata juga dapat menjadi faktor terjadinya disintegrasi bangsa.

Maraknya konflik bernuansa agama yang terjadi di negeri ini mengundang rasa keprihatinan tersendiri bagi berbagai pihak. Melekatkan agama sebagai satu varian potensial pemicu kekerasan sebenarnya bukan hal yang tidak mudah. Hal ini disebabkan karena agama dianggap sebagai ajaran yang selalu diasosiasikan sebagai ajaran yang sarat akan nilai-nilai kedamaian dan keselamatan. Wajah sejuk agama sejatinya sangat tidak mungkin dilekatkan dengan wajah panas dan kekerasan. Imam Priyo Handoko dalam tulisan yang dikutip oleh (Syukron, 2017) mengungkapkan fakta yang terjadi pada beberapa kasus menunjukkan bahwa agama dapat pula menjadi pemicu terjadinya tindak kekerasan. Dalam hal ini pemeluk agama menjadikan doktrin agama sebagai pembenaran atas tindakan yang mereka lakukan

Tindak kekerasan yang mengatasnamakan agama sering kali diterjemahkan oleh sebagian orang sebagai legal doktrin yang harus dilaksanakan. Ia seringkali dimanipulasi oleh kepentingan pihak-pihak tertentu. Kekerasan atas nama agama dapat diterjemahkan sebagai kekerasan yang melibatkan agama sebagai premium variant.

Penggunaan elemen agama sebagai generator konflik seakan melegitimasi berkembangnya tafsir atas konflik sebagai sebuah perang suci. Dimana ayat-ayat suci diberi makna untuk mendukung perang. Doa dan pemberkatan kepada pasukan perang juga dilakukan para pendeta di dalam dan luar gedung gereja. Kidung-kidung rohani pun berganti maknanya menjadi kidung penyemangat perang. Nur Sahid menyebut legitimasi atas nama agama sebagai "kepatuhan buta" (Sahid, Rubianti, Mubarok, Wahyuningroem, Bagir, Rafsadie, 2018).

Isu seputar persoalan agama merupakan isu yang sangat sensitif. Begitu sensitifnya persoalan agama bagi masyarakat Indonesia, konflik sosial dan politik yang sebenarnya di luar agama pun seringkali ditarik ke wilayah agama untuk mendapatkan dukungan yang lebih banyak dari pemeluknya. Konflik 
berlatarbelakang agama kadang-kadang masih terjadi, termasuk di era reformasi, seperti konflik Ambon, Poso, Sampit, Ciketing, Yasmin, dan lain-lain. Konflik-konflik ini, sebenarnya tidak diawali oleh faktor agama, tetapi persoalan ekonomi, sosial, dan hukum secara umum. Hanya saja, kemudian para pelakunya melibatkan agama untuk mendapatkan dukungan emosional dari kelompok agama. Dalam hal ini, agama dimanfaatkan sebagai faktor pemersatu (integratif) bagi komunitas agama tertentu, tetapi menjadi faktor pemecah belah (disintegratif) antarkelompok agama yang berbeda.

Konflik Maluku yang terjadi di tahun 1999 merupakan sebuah catatan hitam tragedi kemanusiaan terbesar dalam sejarah hubungan antar umat beragama di Indonesia. Konflik tersebut patut dicatat sebagai peristiwa terburuk dalam lembaran sejarah hubungan sosial bermasyarakat dan beragama di Indonesia.

Konflik Maluku telah mencabik urat akar dasar kemanusiaan (Rahawarin, 2017). Peristiwa hitam ini bukan saja telah menghancurkan relasi, struktur dan sistem sosial masyarakatnya seperti jatuhnya korban jiwa, harta benda yang tak terkira, tetapi juga telah meluluhlantakkan bangunan sendi etika, norma dan moral kemanusiaan sebagai nilai universal tertinggi yang menjadi pijakan manusia dalam kehidupan. Lebih lanjut Muqoyyidin mengutip pernyataan I Marsana Windu memaknai kekerasan sebagai suatu sifat atau keadaan yang mengandung kekuatan, tekanan dan paksaan (Muqoyyidin, 2012).

Kesenjangan sosial ekonomi di masyarakat merupakan salah satu masalah penyebab terjadinya konflik Ambon di tahun 1999. Orang-orang pendatang yaitu etnis Bugis, Buton, dan Makassar, yang beragama Islam dikenal sebagai pekerja keras dan sukses. Mereka menikmati taraf kehidupan ekonomi yang lebih baik daripada penduduk Ambon sendiri yang mayoritas beragama Kristen. Situasi ini menyebabkan terjadinya tumpukan kesenjangan dan kecemburuan sosial dari masyarakat Ambon terhadap etnis pendatang.

Konflik komunal yang terjadi di Ambon bermula pada 22 Desember 1999. Konflik ini dipicu oleh perselisihan antara preman asal Ambon yang bertempat tinggal di Ketapang, Jakarta, yang masing-masing terdiri dari kelompok Muslim dan Kristen. Kerusuhan dipicu oleh perebutan lahan parkir di tempat hiburan dan perjudian yang dikuasai preman Kristen. Pertengkaran yang sebetulnya berskala kecil ini kemudian membesar karena pada esok harinya beredar kabar bahwa sekelompok geng Kristen telah memukul seorang Muslim dan membakar sebuah Mesjid (Braithwaite, Braithwaite, Cookson, 2010).

Konstalasi konflik pun menjadi meluas 
saat polisi memulangkan sekitar lebih dari 100 anggota geng yang terlibat kerusuhan Ketapang ke Ambon. Pada titik inilah awal mula terjadinya konfllik Ambon. Braithwaite menuliskan bahwa ada seruan baik dari kelompok Islam dan Kristen untuk melanjutkan pertikaian diantara kedua kelompok itu. Adanya rumor yang menyebutkan bahwa ada mobilisasi untuk membela komunitas masing-masing, adanya pembantaian besar-besaran oleh atau atas kelompok Muslim, desakan agar orangorang Kristen tidak menjadi pengecut dan lain sebagainya. Beredar juga laporan tentang adanya provokator Muslim yang berkeliling menggunakan sepeda motor untuk meneriakkan berita palsu, seperti tentang kabar sebuah masjid yang dibakar, padahal sebenarnya hanya ada tumpukan ban yang menyala di belakang masjid. Legitimasi konflik juga diperkuat oleh keyakinan transenden bahwa sekelompok orang melihat penampakan Yesus dan Bunda Maria di sisi Kristen, atau kuda perang di pihak Islam.

Konflik komunal yang mematikan pertama kali meledak pada 13 Januari 1999 di kota kecil Dobo, Kepulauan Aru, jauh di sebelah Tenggara Ambon. Konflik ini juga diawali dari insiden kecil di antara pemuda yang meningkatkan kebencian baik atas kaum Muslim maupun Kristen. Setelah itu, sekitar belasan orang terbunuh dalam empat hari berikutnya.

Selanjutnya, pada Mei 1999, konflik kekerasan lainnya kembali pecah. Saat itu Partai Demokrasi Indonesia Perjuangan (PDIP) memenangi pemilu. PDIP berkoalisi dengan Partai Demokrasi Indonesia (PDI) dan lima partai pendukung lainnya, dimana salah satunya adalah Partai Kristen Indonesia (Parkindo), yang didukung komunitas Kristen Ambon. Karena itu, PDIP kemudian diasosiasikan sebagai "Partai Kristen” di Maluku. Ketika hasil pengumuman menyatakan bahwa PDIP sebagai partai pemenang, perang saudara pun meledak. Orang-orang dikerahkan untuk membela agama mereka dan menyatakan perang dengan mereka yang berbeda agama. Puncak konflik terjadi bertepatan dengan perayaan Natal pada 28 Desember 1999 di Gereja Silo. Gereja tersebut berada di pusat Kota Ambon dan merupakan salah satu Gereja Protestan Maluku (GPM) terbesar yang dibakar. Pada hari yang sama, hampir 800 Muslim yang tengah berada di masjid tepatnya di Desa Tobelo Provinsi Maluku Utara dibunuh oleh komunitas Kristen, selama periode konflik ini banyak desa diserang, baik gereja maupun masjid hancur, serta warga sipil terbunuh dan terlantar (Sahid, Rubianti, Mubarok, Wahyuningroem, Bagir, Rafsadie, 2018).

Konflik Maluku tidak hanya merenggut korban dari pria dewasa diantara kedua belah pihak yang bertikai. Kerusuhan ini juga menghancurkan masa depan anak-anak baik di 
kelompok Islam maupun Kristen. Ada ratusan anak baik dari pihak Islam maupun Kristen yang dilatih, dipersenjatai. Tentara-tentara anak ini bertugas membeli peluru, mematamatai, merazia pengungsi, dan merakit bom (Setiyanto, 2018).

Kondisi sosial dan kehidupan umat beragama masyarakat Maluku pasca disepakatinya Perjanjian Damai Malino II tahun 2002 secara umum selintas terkesan sudah normal dan pulih kembali. Namun, jika kita telusuri lebih dalam rasa khawatir, curigamencurigai justru masih menjadi bagian dalam menjalani kehidupan masyarakat beragama di Maluku. Ibarat api dalam sekam, sewaktuwaktu dapat tersulut kembali.

Di tengah kondisi keterpurukan inilah anak-anak yang menjadi korban konflik Maluku dituntut untuk mampu menjaga kesinambungan hidup yang optimal, maka diperlukan kemampuan untuk menjadi resilien. Resilien yang dimaksud di sini adalah anak-anak yang menjadi korban konflik terdorong untuk bangkit dari keterpurukan dan kembali ke keadaan yang normal.

Kemampuan untuk bangkit dari keterpurukan yang terjadi dalam situasi tersebut menurut Self Resilience Theory berarti kemampuan untuk pulih kembali dari suatu keadaan, kembali ke bentuk semula yang telah dibengkokan, ditekan atau diregangkan. Bila digunakan sebagai istilah psikologi, resiliensi adalah kemampuan manusia untuk cepat pulih dari perubahan, sakit, kemalangan, atau kesulitan (Hitiyahubessy \& Utami, 2015).

Seseorang yang berhasil menjadi resilien maka ia akan menunjukkan kemampuan adaptasi yang lebih dari cukup ketika individu tersebut menghadapi kesulitan. Resiliensi merupakan kemampuan yang dimiliki individu untuk menyesuaikan diri serta beradaptasi atas berbagai macam perubahan, tuntutan, dan kekecewaan yang muncul dalam kehidupannya. Resiliensi juga dimaknai sebagai sebuah kemampuan untuk secara efektif menghadapi stress internal, misalnya dalam hal ini kelemahan-kelemahan yang ada pada diri mereka sendiri maupun stress eksternal (yang berasal dari luar diri mereka).

Di Maluku sendiri khususnya di Maluku Tengah, ada sebuah budaya yang dikenal dengan Pela Gandong. Aziz Tunny dalam Yudhi mengemukakan peran Pela Gandong dalam terciptanya rekonsiliasi (Yudhi, 2011). Lebih lanjut Imam Yudhi mengutip pernyataan Steger yakni suatu sistem sebaran ide, kepercayaan yang membentuk sistem nilai dan norma serta peraturan ideal yang diterima sebagai fakta dan kebenaran oleh kelompok tertentu merupakan ideologi.

Pela Gandong sendiri merupakan kultur khas yang dimiliki orang Maluku. Pela diartikan 
sebagai suatu relasi perjanjian persaudaraan antara satu negeri dengan negeri yang lain dan kadang juga dengan agama yang berbeda. Gandong sendiri memiliki makna bersaudara. Lebih lanjut Tualeka berpendapat Pela Gandong dapat pula diartikan sebagai hidup berdampingan dengan penuh rasa tanggung jawab dalam perbedaan agama (Tualeka, 2011).

Cahaya dari Timur: Beta Maluku adalah sebuah film drama yang dikeluarkan pada bulan Juni 2014 lalu. Film ini diproduseri oleh Almarhum Glenn Fredly dan Angga Dwimas Sasongko. Angga Dwimas Sasongko selain menjadi produser juga turut berperan sebagai sutradara dalam film ini. Film ini merupakan kisah nyata tentang kehidupan seorang pelatih sepak bola di kotaAmbon. Film ini menceritakan bagaimana perjuangan masyarakat di kota Ambon, yang dalam hal ini menampilkan tokoh Sani Tawainella yang mencoba mengobati luka di jiwa anak-anak Ambon akibat konflik komunal lewat sepak bola. Film ini mengambil latar Kota Ambon dan Desa Tulehu (Maluku Tengah) di tengah konflik berdarah pada 1999-2000 dan beberapa tahun setelah konflik berakhir. Peneliti tertarik mengangkat film ini sebagai objek penelitian karena film ini dapat mengajarkan kepada penonton khususnya anakanak Indonesia bagaimana menjaga toleransi di tengah keberagaman yang ada. Film ini juga mengingatkan kita semua tentang persaudaraan dan cintai tanah air dan bangsa sebagai tujuan dari berbangsa dan bernegara.

Sani Tawainella (diperankan oleh Chicko Jerikho) sehari-harinya bekerja sebagai tukang ojek di Tulehu, sebuah desa di tepi laut, di luar Kota Ambon, Maluku. Saat konflik pecah, hatinya resah melihat anak-anak ikut jadi korban. Perseteruan antar umat beragama, juga penjarahan jadi tontonan, bahkan "permainan" buat anak-anak. Sani ingin dengan kemampuannya melatih sepak bola dapat menghapus kenangan buruk di kepala dan hati anak-anak di kampungnya. Ia tidak ingin anakanak di kampungnya hanya mengingat kenangan buruk seputar konflik komunal yang terjadi di Maluku semasa hidu mereka. Ia pun bertekad "menjauhkan" anak-anak di kampungnya dari pusaran konflik dengan melatih sepak bola setiap sore.

Upaya Sani membina anak-anak ini membuat ia dipercaya membentuk tim untuk mewakili Maluku berlaga di Indonesia Cup usia 15 tahun di Jakarta. Tim yang dibentuk Sani mencoba menyatukan anak-anak dari Tulehu yang Muslim dengan anak-anak Passo yang Kristen. Rekonsiliasi memang tengah digiatkan saat itu, akan tetapi, luka batin anak-anak itu tidak serta merta sembuh sepenuhnya.

Film ini kaya akan pergulatan emosi yang kuat. Dalam alur ceritanya dikisahkan seorang anak Tulehu bernama Salembe, misalnya, ia 
sebetulnya tidak merasa memiliki masalah dengan teman-teman satu timnya yang beragama Kristen, akan tetapi ia sangat marah ketika tahu teman satu timnya anak polisi. Ayah Salembe tewas karena terkena peluru polisi pada saat kerusuhan. Di sinilah terlihat bagaimana perjuangan anak-anak korban konflik Maluku melakukan proses resiliensi pasca konflik komunal Maluku.

Dalam penelitian ini, peneliti ini memilih pendekatan kualitatif dengan metode Analisis Wacana Kritis Norman Fairclogh. Analisis Wacana Kritis peneliti gunakan sebagai sarana untuk membongkar sesuatu yang salah atau tidak beres di masyarakat, seperti adanya ketidakadilan, ketaksetaraan, pembatasan kebebasan atau diskriminasi (Haryatmoko, 2016).

Tujuan lain yang hendak dicapai oleh CDA adalah menganalisis praktik wacana yang mencerminkan atau mengkonstruksi masalah sosial; selain itu, AWK juga meneliti bagaimana ideologi dibekukan dalam bahasa dan menemukan cara bagaimana mencairkan ideologi yang mengikat bahasa. Berdasarkan latar belakang di atas maka rumusan masalah dalam penelitian ini adalah bagaimana wacana resiliensi anak-anak korban konflik Maluku pada film Cahaya dari Timur: Beta Maluku.

Konflik sendiri berasal dari kata bahasa latin configere yang berarti saling memukul.
Secara sosiologis, konflik diartikan sebagai sebuah proses sosial antara dua orang atau lebih (bisa juga kelompok) dimana salah satu pihak berusaha menyingkirkan pihak lain dengan menghancurkannya atau membuatnya tidak berdaya (Rudiansyah, 2016). Dalam kehidupan umat manusia, konflik bukanlah sesuatu yang baru. Ia telah menjadi sesuatu yang selalu ada, entah tampil dalam bentuk laten ataupun manifest. Pada masyarakat yang tertutup biasanya konflik laten lebih sering muncul, sedangkan konflik yang termanifestasikan secara real, umumnya dipicu oleh berbagai sebab dan lingkungan sosial yang bersifat “transisi”, tapi juga konflik jenis ini sering pula dipicu oleh keinginan suatu kelompok, negara atau etnis untuk menguasai negara, kelompok, atau etnis lain.

Sebagai bagian dari media massa Film berupaya untuk menjalankan fungsinya sebagai media pendidikan, hiburan, informas, dan juga mendorong tumbuhnya industri kreatif. Film juga diyakini memiliki kemampuan persuasif yang besar kepada para penontonnya (Maulany \& Abdullah, 2019).

Film merupakan media penyampai pesan dan alat komunikasi massa. Pernyataan ini acap terdengar bila kita masuk dalam kajian perfilman. Film, dan media pada umumnya, dapat menjadi alat propaganda yang ampuh Bahkan UU Film Indonesia menyebut film 
sebagai "...karya seni budaya memiliki peran strategis dalam peningkatan ketahanan budaya bangsa dan kesejahteraan masyarakat lahir batin untuk memperkuat ketahanan nasional" dan "film sebagai media komunikasi massa merupakan sarana pencerdasan kehidupan bangsa, pengembangan potensi diri, pembinaan akhlak mulia, pemajuan kesejahteraan masyarakat, serta wahana promosi Indonesia di dunia internasional" (Syaukat \& Imanjaya, 2011).

Film sebagai bagian dari media massa dinilai dapat menjadi alat yang sangat efektif dalam menyajikan informasi yang menghibur sekaligus mendidik. Kemampuan film dalam menyebarkan pesan ke penontonnya dalam bentuk audio visual merupakan kekuatan tersendiri dalam mengkomunikasikan berbagai macam makna ke dalam bentuk kehidupan sosial. Satria dan Rinaldy mengutip pernyataan Sutorini bahwa Film memiliki kekuatan tersendiri. Ia mampu menyampaikan topik secara luas namun terasa ringan, sehingga mudah dipahami oleh penonton (Satria \& Rinaldy, 2019).

Film juga dapat dikatakan sebagai bagian dari transformasi kehidupan yang ada pada masyarakat, karena film merupakan suatu potret dari masyarakat dimana film itu dibuat. Umumnya film akan merekam realitas yang tumbuh dan berkembang dalam masyarakat yang kemudian divisualisasikan ke dalam layar agar dapat disaksikan oleh khalayak ramai.

Menurut paham analisis wacana kritis (Critical Discourse Analysis), teks bukanlah sesuatu yang bebas nilai dan menggambarkan realitas sebagaimana adanya. Kecenderungan pribadi dari sang produsen teks dan struktur sosial yang melingkupi sang produsen teks ikut mewarnai isi teks. Bahasa tidak netral melainkan membawa pesan ideologi tertentu yang dipengaruhi oleh sang pembuat teks. Oleh karenaitu, dalam memahami wacana,AWK tidak semata-mata sebagai suatu studi bahasa, tetapi analisis wacana kritis juga menghubungkannya dengan konteks. Konteks yang dimaksud di sini adalah bagaimana konteks praktik kekuasaan yang bertujuan untuk memarginalkan individu atau kelompok tertentu melalui penggunaan kekuasaan dalam memproduksi sebuah teks (wacana).

Fairclough menyebut pemahamannya tentang bahasa dengan istilah discourse atau wacana (Wachidah \& Fauzan, 2018). Konsep wacana menurut Fairclough merupakan bentuk dari sebuah "praktik sosial" yang memiliki tiga implikasi. Pertama, wacana merupakan bagian dari masyarakat. Wacana tidak bisa berdiri sendiri dengan dipisahkan dari masyarakat. Kedua, pemahaman wacana sebagai praktik sosial memberi implikasi bahwa wacana merupakan proses sosial. Sebagaimana 
masyarakat berproses dan berkembang, maka wacana (bahasa) juga berproses dan berkembang. Ketiga, wacana berproses sesuai dengan yang dikondisikan dalam masyarakat. Ada semacam dialektika antara bahasa dan kondisi sosial. Wacana dipengaruhi oleh kondisi sosial, akan tetapi kondisi sosial juga dipengaruhi oleh wacana.

Bahasa menurut Fairclough memiliki dua peran, pasif dan aktif. Dalam peran pasifnya, bahasa merupakan alat rekam dari apa yang berlangsung dalam kehidupan manusia. Bahasa lisan yang terekam secara tertulis, seperti Babat Tanah Jawaatau bahasa lisan yang dituturkan seperti dalam bentuk dongeng, mampu mendokumentasikan apa yang terjadi di masa lampau. Bahasa dapat berperan pula sebagai refleksi dari proses sosial yang berlaku di masyarakat. Misalnya, bahasa yang memiliki tingkatan sepertibahasa Madura, enja 'iya-enggi enten-enggi bhunten, merupakan cerminan dari masyarakatnya yang relatif masih berorientasi pada hirarki. Sebagai alat rekam mengenai apa yang terjadi di masyarakat, bangsa Indonesia telah mempraktekkan hal ini sejak ratusan tahun yang lalu, misalnya kejadian dalam sosial masyarakat yang terekam dalam batu-batu di dinding candi Borobudor. Selain berperan secara pasif, bahasa juga dapat berperan secara aktif. Dalam hal ini, bahasa ikut serta menjadi elemen yang menyebabkan terjadinya perubahan sosial itu sendiri (Wachidah \& Fauzan, 2018).

Wacana adalah praksis sosial dalam bentuk interaksi simbolis yang bisa terungkap dalam pembicaraan, tulisan, kial, gambar, diagram, film, atau music (Fairclough, 2010). Objek kajian dalam AWK sendiri bersumber dari dokumen, kertas diskusi, perdebatan parlemen, piadto, kartun, film, foto, koran, iklan, atau brosur.

Asumsi dasar AWK ialah bahwa bahasa digunakan untuk beragam fungsi dan bahasa mempunyai berbagai konsekuensi. Bisa untuk memerintah, memengaruhi, mendeskripsi, mengiba, memanipulasi, menggerakan kelompok atau membujuk. Setiap penggunaan bahasa mengandung konsekuensi-konsekuensi, baik yang bisa diramalkan maupun yang tidak diharapkan. Dalam penggunaan bahasa, ada retorika, manipulasi dan penyesatan.

Menurut Bourdieu, makna bahasa juga berasal dari luar bahasa, bukan hanya hasil hubungan gramatikalnya. Wacana dikonstruksi bukan hanya dari sisi sintaksisnya saja, namun juga dari faktor yang di luar bahasa. Konstruksi muncul ketika orang mencoba memberi makna kepada suatu fenomena atau ikut terlibat dalam aktivitas sosial disadari/tidak. Bahasa itu dikonstruksi dan mengkonstruksi masyarakat. Maka bahasa berubah sesuai dengan konteks dan situasi berubah mengikuti bahasa yang digunakan (Haryatmoko, 2016). 


\section{METODE PENELITIAN}

Penelitian ini menggunakan pendekatan kualitatif dengan metode Analisis Wacana Kritis Norman Fairclogh. Wacana adalah struktur cerita yang bermakna atau sebuah bentuk sajian yang memuat satu atau lebih gagasan dengan menggunakan bahasa (verbal dan non verbal) (Hamad, 2007). Analisis Wacana Kritis mencoba untuk membongkar adanya sesuatu yang salah atau sesuatu yang tidak beres di masyarakat, seperti ketidakadilan, ketidaksetaraan, pembatasan kebebasan maupun diskriminasi. there are a three-dimensional method of discourse analysis. Discourse, and any specific instance of discursive practice, is seen as simultaneously (i) a language text, spoken or written, (ii) discourse practice (text production and text interpretation), (iii) sociocultural practice (Fairclough, 2010).

Hal mendasar yang perlu dianalisis dalam analisis teks adalah penggunaan perbendaharaan kata yang terkait dengan makna tertentu, penggunaan istilah dan metafora karena mengacu kepada makna atau tindakan tertentu.

Perbendaharaan kata meliputi kata: satu kata dapat mempunyai banyak makna, dan makna berbeda tergantung dari konteksnya. Maka diperlukan kejelian untuk memahaminya. Struktur teks terkait dengan bagaimana logika argumen untuk pembenaran disusun dan disistematisasi (Haryatmoko, 2016).

Lebih lanjut, analisis praktik diskursif ingin melihat kekuatan pernyataan dalam arti sejauh mana dapat mendorong tindakan afirmatifnya. Fokusnya adalah bagaimana cara pengarang teks mengambil wacana dan genre yang ada dengan memperhatikan bagaimana hubungan kekuasaan dimainkan.

Analisis praksis sosial. Dalam dimensi ini sudah mulai masuk pemahaman intertekstual, dalam hal ini sudah terlihat bagaimana teks dibentuk dan membentuk praksis sosial. Analisis wacana kritis memiliki dua model, yaitu CDA model Norman Fairclough yang melihat teks (naskah) memiliki konteks dan CDA dari Ruth Wodak yang menilai teks (naskah) mempunyai sejarah. Di dalam buku Critical Discourse Analysis: The Critical Study of Language model CDA memiliki konteks "process of production" atau "text production"nya, "process of interpretation" atau "text consumption" dan berdasarkan praktik sosio kulturalnya.

Menurut Fairclough wacana merupakan sebuah proses semiosis. Wacana sebagai praksis sosial digunakan untuk menganalisis institusi, organisasi, relasi kelompok, struktur, proses sosial-politik. Fairclough membagi Analisis Wacana Kritis ke dalam tiga dimensi: teks, praktik diskursif dan praksis sosial (Haryatmoko, 2016). Teks, adalah segala hal yang mengacu kapada wicara, tulisan, grafik, dan kombinasinya ataupun segala bentuk yang 
berkaitan dengan linguistik teks, misalnya yang berhubungan dengan kata, gramatika, sintaksis, struktur metafora ataupun retorika. Praktik Diskursif, merupakan semua bentuk produksi dan konsumsi teks. Dalam hal ini terdapat proses yang menghubungkan antara produksi dan konsumsi teks. Pada level ini kita dapat melihat bagaimana cara penulis teks mengambil sebuah wacana ataupun genre yang ada dengan memperhatikan bagaimana hubungan kekuasaan dimainkan di dalam teks tersebut. Praksis Sosial, dalam level ini biasanya sudah mulai masuk pemahaman intertekstual, bagaimana sebuah sebuah teks itu dibentuk dan membentuk praksis sosial. Hal mendasar yang perlu kita cermati saat menganalisis teks adalah bagaimana penggunaan perbendaharaan kata yang terkait dengan makna tertentu, penggunaan istilah dan metafora tertentu.

\section{HASIL DAN PEMBAHASAN}

Media massa film juga memiliki fungsi integrasi dan empati. Melalui cerita tentang bagaimana masyarakat di kota Ambon-Maluku bangkit dari keterpurukannya setelah konflim komunal di tahun 2000, para audiens diharapkan dapat memperoleh pengetahuan tentang kondisi orang lain, memunculkan rasa empati dan mempererat persatuan dan kesatuan bangsa.

Sebagai bangsa yang memiliki ciri heterogenitas sosial, Indonesia menyimpan potensi konflik yang cukup besar yang bersumber dari keberagaman identitas tersebut. Perbedaan agama pun menjadi salah satu sumber konflik yang rentan muncul di tengahtengah kondisi masyarakat yang heterogen.

Kejenuhan akan konflik yang berkepanjangan yang berlangsung selama kurang lebih empat tahun menumbuhkan

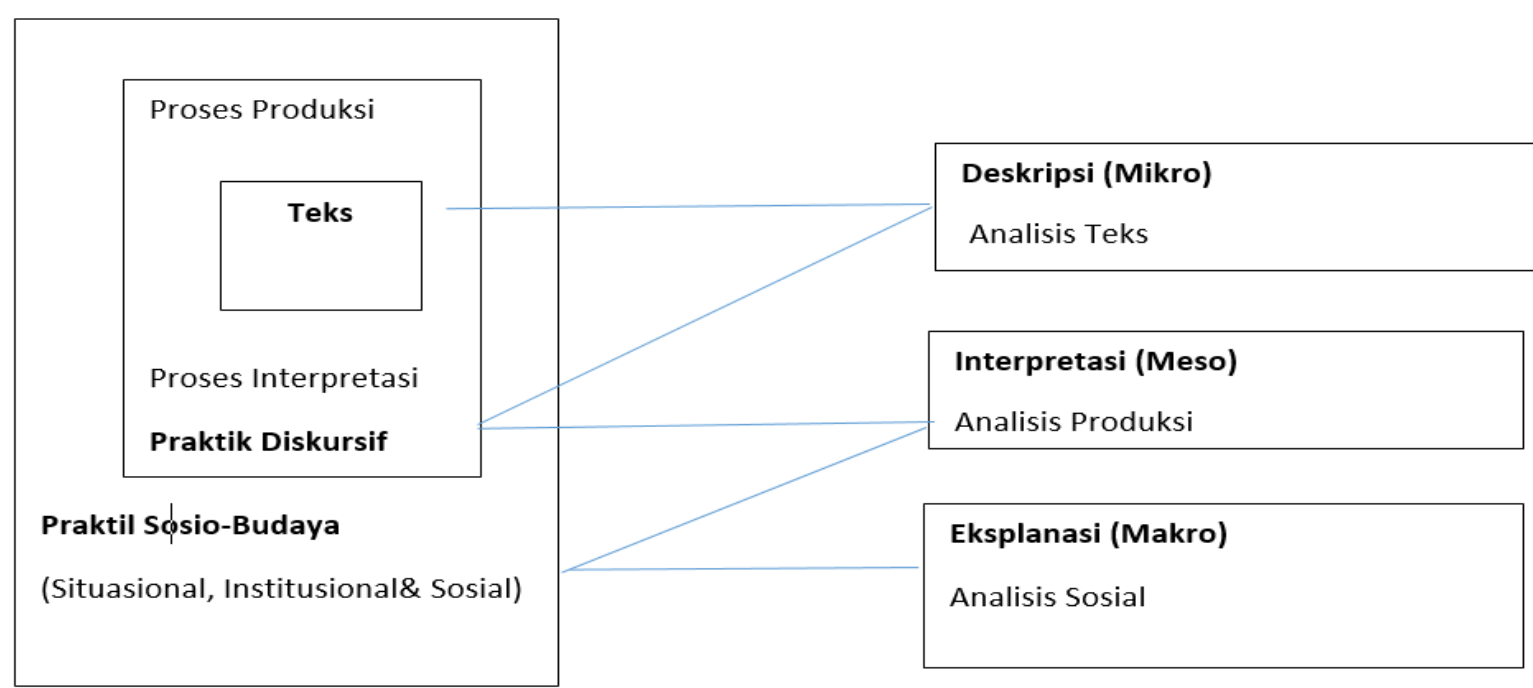

Sumber: (Haryatmoko, 2016)

Gambar 1 Model Tiga Dimensi AWK Fairclough 
kesadaran di dalam hati dan pikiran masyarakat, baik di tataran elit masing-masing pihak yang bertikai maupun masyarakat tingkat bawah yang terutama secara langsung merasakan dampak paling parah dari konflik tersebut. Dampak negatif dari konflik tersebut hal itu juga terlihat pada teks berikut:

Teks 1. Audio Durasi 2:04:27 Dialog Sani dan Tim

Sudah Terlalu banyak sakit dalam hidup kita, karena perang, karena marah, karena nafsu, karena mau menang sendiri.

Teks 2. Audio Durasi 2:0506 Dialog Sani dengan Tim

Sani: saya latih kalian dari kecil itu supaya kalian punya ingatan yang baik, yang bukan soal bom, tembakan, air mata, orang mati. Saya percaya waktu tak akan cukup untuk mencari siapa yang benar dan siapa yang salah, tapi saya percaya satu hal kita harus hidup lebih baik.

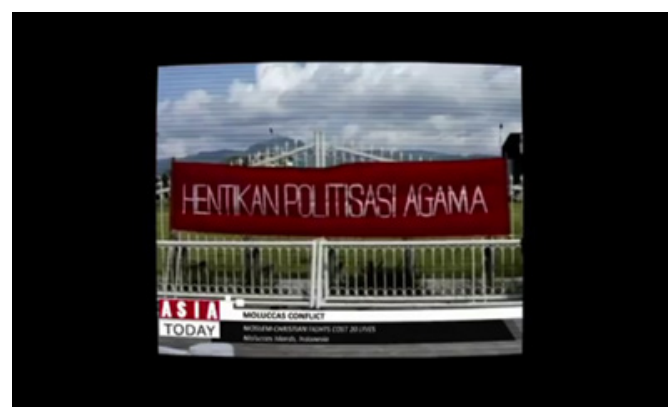

Sumber: Film Cahaya dari Timur: Beta Maluku, 2014

Gambar 2 Durasi: 00:02:28

Memanasnya suhu politik menjelang pelaksanaan Pemilu 1999 dengan beredarnya banyak isu-isu SARA untuk meraih dukungan politik. Peristiwa-peristiwa tersebut telah menjadi pematangan konflik karena menjadi permulaan kristalisasi massa berbeda Agama, terutama Islam dan Kristen di Maluku. Semua yang terlibat dalam konflik Maluku adalah korban, baik dari pihak Islam maupun Kristen. Masyarakat tingkat bawah yang paling merasakan dampak dari konflik horizontal tersebut baik dari kalangan Muslim maupun Kristen.

Adanya persaingan sengit antar lembagalembaga agama lokal seperti dalam upaya memperbanyak pengikut maupun dalam memperluas teritori agama. Persaingan ini terjadi, misalnya antara Gereja Protestan Maluku dengan Majelis Ulama Indonesia Maluku maupun dengan organisasi-organisasi Islam seperti NU dan Muhammadiyah. Juga di Halmahera, antara Gereja Masehi Injili Halmahera (GMIH) dengan lembaga-lembaga Islam setempat. Persaingan ini telah berlangsung lebih dari 157 tahun sejak cikalbakal GMIH didirikan pertama kali di Halmahera Utara.

Pada durasi 01:21:26 terdapat dialog antara tokoh Salembe: “Ini bukan soal Agama, ini soal bola". Penggunaan perbendaharaan kata yang terkait dengan makna tertentu, penggunaan istilah dan metafora mengacu ke makna atau tindakan tertentu.dalam hal ini penulis cerita menggunakan teks seperti politisasi agama ataupun dialog pada durasi 01:21:26 bahwa ini 
bukan soal agama, ini soal bola.

Pada level praktik diskursif, penulis naskah berusaha menggunakan kata-kata dan kalimat ini dimaksudkan agar mempermudah penonton mengidentifikasikan diri. Penulis naskah Irfan Ramli mengungkapkan penggunaan penekanan tertentu pada teks lewat kata ataupun gambar merupakan bagian kohesi antara kalimat dan pemaknaan kata.

"Kalimat provokasi sebenarnya untuk memprovokasi penonton, untuk memprovokasi siapapun untuk bisa secara kritis memisahkan, karena percaya atau tidak kita tuh biasa mencampuradukan sesuatu gitu, agama jadi gak clear gitu, tidak selesai gitu menseparasi antara urusan pribadi dan urasan kelompok atau dalam hal Salembe” (Laksmi Rachmaria, 2018).

Sebuah wacana selalu berkelindan dengan berbagai tingkatannya, baik dalam situasi langsung maupun tidak langsung. Konflik komunal yang terjadi di Maluku sebetulnya bukanlah konflik agama, akan tetapi akibat dari kesenjangan ekonomi antara penduduk asli dengan pendatang. Memanasnya suhu politik menjelang pelaksanaan Pemilu 1999 dengan beredarnya banyak isu-isu SARA untuk meraih dukungan politik. Peristiwa-peristiwa tersebut telah menjadi pematangan konflik karena menjadi permulaan kristalisasi massa berbeda Agama, terutama Islam dan Kristen di Maluku.

\section{Kesadaran Masyarakat Ambon}

Menghentikan Konflik. Konflik Ambon berlangsung selama kurang lebih empat tahun.
Dalam masa empat tahun tersebut korban jiwa dan harta benda tidak terhitung. Hal ini menimbulkan pemikiran dan kesadaran masyarakat akan dampak buruk yang ditimbulkan selama konflik.

Kejenuhan akan konflik yang berkepanjangan ini ternyata timbul disegala aspek masyarakat, baik pada tingkatan elit masing-masing pihak yang bertikai, maupun masyarakat tingkat bawah yang terutama merasakan dampak konflik paling parah. Inilah yang merupakan faktor pendorong utama perdamaian.

Audio: "Kita selalu berdoa untuk keberhasilan dan keselamatan kita”.

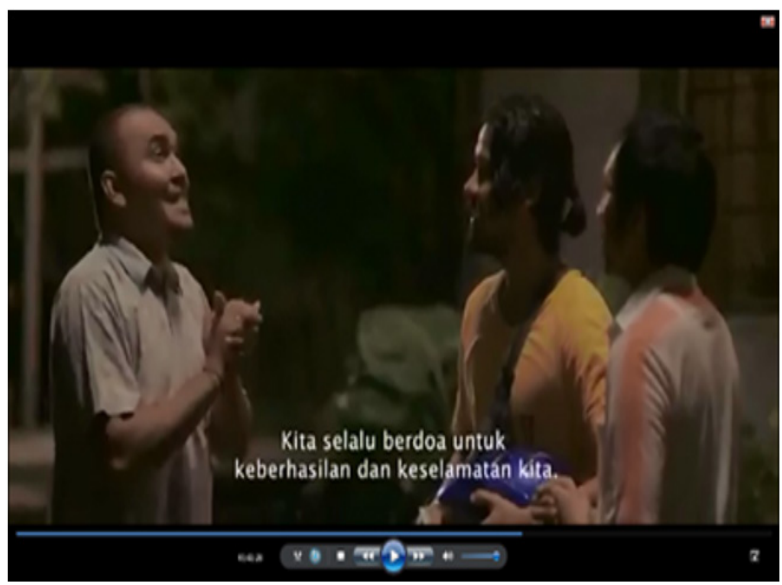

Sumber Film Cahaya dari Timur: Beta Maluku, 2014

Gambar 3 Durasi 01:41:28

Audio: Suasana menonton bersama di Gereja 


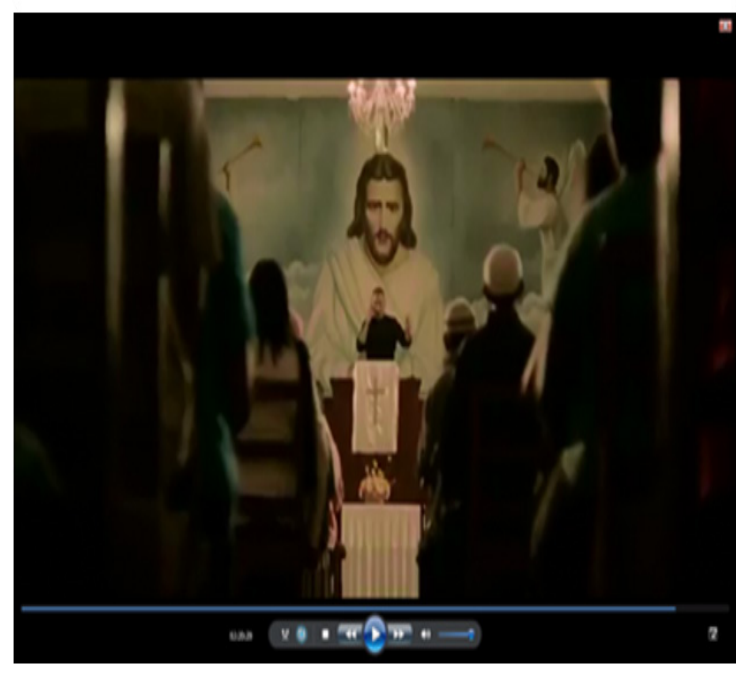

Sumber Film Cahaya dari Timur: Beta Maluku, 2014

Gambar 4 Durasi: 02:20:20

Resiliency means being able to bounceback from life developments that may feel totally overwhelming at first. Secara umum, resiliensi bermakna kemampuan seseorang untuk bangkit dari keterpurukan yang terjadi dalam perkembangannya. Sejumlah ahli yang berbicara tentang resiliensi mengemukakan berbagai definisi resiliensi. Mereka mencoba medefinisikan makna resiliensi menjadi dua sudut pandang utama, yaitu: pertama, resiliensi sebagai kemampuan adaptasi dan resiliensi sebagai kemampuan bangkit dari tekanan. Resiliensi dalam ilmu psikologi dapat dijelaskan sebagai kapasitas positif yang dimiliki manusia dalam melakukan koping, ketika mengalami stres atau menghadapi konflik. Resiliensi pun dapat dipakai untuk menandakan salah satu sifat bertahan terhadap pengalaman negatif pada masa yang akan datang.

Orang yang reseilen menunjukkan kemampuan adaptasi yang lebih dari cukup ketika orang tersebut menghadapi kesulitan. Resiliensi merupakan kemampuan individu untuk menyesuaikan diri dan beradaptasi terhadap perubahan, tuntutan, dan kekecewaan yang muncul dalam kehidupan. Singkatnya, resiliensi data dimaknai sebagai suatu kemampuan untuk secara efektif menghadapi stress internal berupa kelemahan-kelemahan mereka maupun stress eksternal.

Karakteristik individu yang mempunyai resiliensi yang bagus adalah ketika mereka dapat mengatasi perubahan-perubahan dalam hidup, dapat mempertahankan kesehatan dan energi yang baik ketika berada dalam tekanan, dapat bangkit dari keterpurukan, dapat mengatasi kesulitan-kesulitan hidup, dapat merubah cara berfikir dan cara mengatasi masalah ketika cara yang lama tidak berhasil, yang paling penting individu yang resilien dapat melakukan halhal diatas tanpa melakukan tindakan yang berbahaya atau disfungsi.

Konflik Ambon berlangsung kurang lebih empat tahun. Dalam kurun waktu tersebut tak terhitung jumlah korban jiwa maupun harta benda. Situasi ini menimbulkan kesadaran dalam hati dan pikiran masyarakat Ambon secara khusus maupun Maluku secara lebih luas akan dampak buruk yang ditimbulkan selama terjadinya konflik. "sesuatu yang kemudian 
membuat kelompok yang tadinya bertikai ini boleh dibilang bersatu yah, dalam artian bersatu karena pernah hancur, film ini berusaha untuk mengcapture.." (Rachmaria, 2018). Kejenuhan atas konflik yang berkepanjangan justru menyebabkan masyarakat korban konflik bersatu, baik di tingkat elit maupun masyarakat tingkat bawah yang secara langsung merasakan dampak dari konflik komunal tersebut. "bahwa semua yang ada di konflik itu korban maksudnya mau dalam hal ini konflik Maluku Islam Kristen gitu soalnya semua korban" (Rachmaria, 2018).

Konflik yang berkepanjangan ini tidak hanya menimbulkan kerusakan fisik dan korban jiwa, tetapi juga trauma psikologis, khususnya bagi masyarakat yang kehilangan tempat tinggal dan anggota keluarganya pada masa konflik. Rehabilitas mental ini membutuhkan waktu yang tidak sebentar. Sementara di sisi lain perhatian pemerintah lebih berat terfokus pada rehabilitasi fisik. "Dan yang paling menyedihkan dalam situasi konflik-konflik ini, manusia tuh maksudnya masyarakat yah, dalam hal ini adalah tanggung jawab Negara yah, masyarakat itu dipaksa, maksudnya dipaksa untuk menyembuhkan dirinya sendiri," (Rachmaria, 2018).

Kondisi ini melahirkan stereotype, trauma, dan kecurigaan di kalangan masyarakat. Pasca disepakatinya perjanjian damai dalam Perjanjian Malino II tahun 2002, secara umum kondisi sosial dan kehidupan beragama masyarakat Maluku selintas terkesan sudah normal dan pulih kembali. Namun, jika kita telusuri lebih dalam rasa khawatir, curigamencurigai justru masih menjadi bagian dalam menjalani kehidupan masyarakat beragama di Maluku (Rahawarin \& Ambon, 2013).

"Ketika di awal cerita yang dilakukan Sani Taiwainella itu kan cari sesuatu ke kota , maksudnya masyarakat itu dalam kehidupan yang sulit, dan ketika kerusuhan itu terjadi, maksudnya semua orang bisa mati, semua orang bisa jadi korban..semua orang bisa terluka, dan kalau ditanya dimana tanggung jawab Negara pada waktu itu hampir boleh dibilang tidak ada, dalam artian masyarakat berusaha menghealing dirinya sendiri, menyembuhkan dirinya sendiri, ini hal-hal yang pengen kita sampaikan” (Rachmaria, 2018).

"ketika mereka semua jadi korban pertanyaan siapa yang menyelamatkan mereka...oke ada bantuan Negara, ada fasilitas yang dibangun dari bantuan baik swasta maupun pemerinta, tapi hal paling mendasar hal yang paling fundamental bahwa manusia... manusia-manusia ini orang orang ini maksudnya dia menyalamatkan dirinya mereka sendiri”" (Rachmaria, 2018).

Dalam fungsi yang ketiga tentang Negara sebagai pengatur ketertiban, telah gagal melaksanakan fungsi yang ketiga ini, kenapa? karena ketetiban tidak terlaksana dengan baik, Negara dan Segi fungsi tentang pertahanan atau agresi Militer juga gagal membuat masyarakat tidak ada rasa percaya lagi terhadap pihak Militer yang ada di Maluku, karena pada saat itu rakyat sudah tidak memandang pihak 
keamanan lagi. Peran Militer dan Aparat dalam Menjaga Stabilitas Pasca Konflik. Meskipun pasca penetapan Darurat militer oleh presiden Abdurrahman Wakhid, keterlibatan militer di Ambon dikecam, ditambah lagi dengan hilangnya kepercayaan masyarakat akan netralitas militer dan apparat.

Konflik yang terjadi di Maluku memiliki dimensi yang sangat kompleks dimana akar permasalahan sebenarnya adalah ketimpangan ekonomi antara kaum pendatang dengan masyarakat asli, yang kemudian dibawa ke arah sentimen agama. Oleh karena itulah dibutuhkan upaya resolusi konflik yang tidak hanya bersifat melerai dan menghentikan kekerasan, tetapi juga dibutuhkan suatu rekonstruksi sosial dan penguatan identitas lokal yang ada di kedua wilayah tersebut.

Sebagai negara yang multikultural, Indonesia kaya akan keberagaman. Berbagai agama, suku, ras dan budaya hidup di dalamnya. Heterogenitas ini menyebabkan Indonesia rentan terjadi konflik. Mulai konflik sosial hingga konflik agama. Konflik sejatinya merupakan sesuatu yang lumrah terjadi di masyarakat, akan tetapi konflik akan menjadi masalah yang serius jika konflik tersebut terjadi secara berkepanjangan dan merusak nilai-nilai kebhinnekaan bangsa Indonesia.

Konflik Maluku 1999 adalah tragedi kemanusiaan terbesar dalam sejarah hubungan antar umat beragama di Indonesia. Konflik tersebut patut dicatat sebagai peristiwa terburuk dalam lembaran sejarah hubungan sosial bermasyarakat dan beragama di Indonesia. Konflik Maluku telah mencabik urat akar dasar kemanusiaan. Peristiwa hitam ini bukan saja telah menghancurkan relasi, struktur dan sistem sosial masyarakatnya seperti jatuhnya korban jiwa, harta benda yang tak terkira, tetapi juga telah meluluhlantakkan bangunan (Rahawarin \& Ambon, 2013).

Wilayah konflik merupakan wilayah yang rentan dengan tindakan kekerasan terutama kekerasan pada anak-anak dan perempuan. Salah satu wilayah konflik berdarah di Indonesia yang memberi dampak negatif bagi perempuan baik secara langsung maupun tidak langsung adalah konflik Ambon. Konflik yang terjadi pada 19 Januari 1999 ini memberi dampak yang sangat luas bagi kehidupan sosial masyarakat. Konflik ini membuat banyak orang kehilangan anggota keluarganya, harta benda dan mata pencarian.

Kerusuhan Ambon ini telah berdampak negatif bagi mereka yang mengalami langsung peristiwa tersebut. Harsono (2009) mengatakan bahwa kejadian yang sudah berlangsung pada tahun 1999 itu tetap memberikan trauma tersendiri bagi anak-anak yang mengalami kerusuhan di Ambon, terutama bagi remaja. Peristiwa kerusuhan tersebut tetap teringat oleh mereka dan tetap terasa sampai sekarang karena 
menyebabkan rasa kesedihan dan kehilangan yang mendalam. Seseorang yang mengalami suatu peristiwa menyakitkan atau yang tidak menyenangkan seperti kerusuhan Ambon tersebut, membutuhkan suatu kemampuan untuk bertahan dan beradaptasi atas peristiwa yang dialami. Kemampuan untuk bertahan dan beradaptasi atas peristiwa yang dialami ini disebut dengan resiliensi. Melalui resiliensi, mereka yang mengalami dan menjadi korban kerusuhan, terutama remaja akan dapat memiliki kemampuan untuk bertahan dan menghadapi situasi yang tidak menyenangkan tersebut.

Adanya toleransi antara umat beragama yang sangat kental sekali dalam film ini, yang dimana pada akhirnya di film ini bukan hanya menang dari sebuah kompetisi sepak bola, melainkan juga menang dari setiap masalah yang dihadapi oleh Maluku yaitu soal kerusuhan antara Agama Muslim dan Kristen, yang dimana diawal sudah sangat jelas kalau Maluku itu dulu kerusuhan karena sebuah isu pemantik yaitu Agama dimana orang Maluku sendiri sangat sensitive dan orang maluku sangat lah Agamis jika di sentil denga masalah agama masyarakat Maluku akan lebih sesntif, dan kembali seperti yang dikaata Irfan sebagai penulis naskah bahwa kebanggan bisa menembus batas batas, yang tadi mereka saling membenci satu dengan yang lain, tetapi sekarang mereka bersatu untuk kebanggan mereka bersama dan mereka tidak lagi latar belakang mereka itu dan Agama mereka itu apa, disini juga dibilang bahawa rakyat Maluku sampai sekarang sudah hidup berdamai tidak ada lagi kata membenci satu dengan yang lain dan disini mereka saling "Gandong" artinya adalah saling menopang. Dan dalam bagian seorang bapak menyanyikan lagu "Hena Masa Waya" itu sendiri artinya: Lagu ini menceritakan tentang perjuangan Maluku, dan lagu ini sebenarnya adalah lagu leluhur. Dan lagu ini sebenarnya sudah ada sebelum Republik ini ada, lagu ini sudah ada. Dan lagu ini adalah lagu identitas yang menunjukan Maluku, dan lagu ini juga menjadi lagu perdamaian buat kerusuhan di Maluku dan menjadikan lagu persatuan buat rakyat Maluku. Pela-Gandong merupakan merupakan ideologi yang diturunkan oleh leluhur Maluku. Pela bukanlah suatu agama tetapi dalam ikatan Pela itu terkandung nilai-nilai agamawi yang berkaitan dengan kepercayaan kepada Tuhan sang pencipta dan para leluhur (tete-nene moyang) sebagai yang mengatur kehidupan manusia. Pembentukan Pela lebih banyak didorong inisiatif penduduk. Kenyataan ini sungguh penting terutama untuk melihat masa depan. ketaatan terhadap perjanjian juga sekaligus ketaatan terhadap kekuasaan raja dan warga masyarakat. Pelanggaran terhadap ikatan perjanjian dari warga negeri akan mendapatkan sanksi dari pemerintah negeri. 


\section{SIMPULAN}

Wacana merupakan hasil proses strategis konstruksi atau memberi makna dengan menggunakan unsur-unsur teks yang penggunaannya berkaitan erat dengan konteks social dimana teks tersebut diproduksi. Pada level teks film Cahaya dari Timur: Beta Maluku menggambarkan bagaimana kondisi anak-anak korban konflik komunal Maluku untuk bangkit dari keterpurukan, berjuang mengobati luka batin akibat konflik komunal. Pada level praksis kewacanaan menekankan tentang kegagalan pemerintah dalam melakukan rehabilitasi sosial masyarakat. Level sosiokultural masyarakat sesungguhnya merupakan korban dari politisasi agama. Ideologi Pela-Gandong merupakan kultur khas Maluku sebagai sarana penyelesaian konflik komunal.

\section{DAFTAR PUSTAKA}

Braithwaite, J., Braithwaite, V., Cookson, M. (2010). Anomie and violence: non-truth and reconciliation in Indonesia Peacebuilding. Australian National University Press.

Fairclough, N. (2010). Critical discourse analysis the critical study of language (second). Pearson Education Limited.

Hamad, I. (2007). Lebih dekat dengan analisis wacana. MediaTor, 8(2), 325-344.

Haryatmoko. (2016). Critical discourse analysis (analisis wacana kritis) landasan teori, metodologi dan penerapan. Kanisius. Hitiyahubessy, A. A. \& Utami, M.S. S. (2015).
Resiliensi perempuan korban konflik ambon. Prediksi, Kajian Ilmian Psikologi, 4(1), 19-32.

Imam Y. P. (2011). Pergeseran peran ideologi dalam partai politik. Jurnal Ilmu Politik Dan Ilmu Pemerintahan, 1(1), 30-40.

Maulany, S. P., \& Abdullah, A. (2019). Pemberitaan film A Man Called Ahok dan film 212 di media online. ProTVF, 3(2), 155. https://doi.org/10.24198/ptvf. v3i2.22940

Muqoyyidin, A. W. (2012). Potret konflik bernuansa agama di Indonesia (signifikansi model resolusi berbasis teologi transformatif). Analisis: Jurnal Studi Keislaman, XII(2), 315-340.

Rahawarin, Y. (2017). Kerjasama antar umat beragama: studi rekonsiliasi konflik agama di Maluku dan Tual. Kalam, 7(1), 95. https://doi.org/10.24042/klm.v7i1.451

Rahawarin, Y., \& Ambon, U. P. (2013). kerjasama antar umat beragama: studi rekonsiliasi konflik agama di Maluku dan Tual. Kalam: Jurnam Studi Agama Dan Pemikiran Islam, 7(1), 95-120.

Rachmaria, L. (2018). Interview Irfan Ramly, Script Writer.

Rudiansyah, D. (2016). Dimensi sosio-politik konflik Ambon. Jurnal Sosiologi Reflektif, 10(1), 161. https://doi.org/10.14421/jsr. v10i1.1143

Sahid; Rubianti, F.; Mubarok, H.; Wahyuningroem, S. L.; Bagir, Z. A.; Rafsadie, I. (2018). Keluar dari ekstrimisme delapan kisah: hijrah" dari kekerasan menuju binadamai (D. A. Kartika, Ihsan Ali-Fauzi (ed.); 1st ed.). Pusad Studi Agama dan Demokrasi, Yayasan Wakaf Paramadina.

Satria, B. R., \& Rinaldy, R. (2019). Sikap penonton terhadap film nasionalisme 
(Jenderal Soedirman). ProTVF, 3(2), 200. https://doi.org/10.24198/ptvf.v3i2.21613

Setiyanto, A. (2018). Kisah mereka, korban konflik Maluku. Independen.Id. http:// independen.id/read/orang/581/kisahmereka-korban-konflik-maluku/

Syaukat, R., \& Imanjaya, E. (2011). Film sebagai media social marketing: Yasmin Ahmad berjualan ide multikulturalisme Rosidah Syaukat; Ekky Imanjaya. Humaniora, 2(1), 634-642.
Syukron, B. (2017). Agama dalam pusaran konflik. Ri'ayah, 02(01).

Tualeka, H. (2011). Kearifan lokal pela-gandong di lumbung konflik. El Harakah Jurnal Budaya Islam, 13(2). http://ejournal.uinmalang.ac.id/index.php/infopub/article/ view/457/pdf

Wachidah, S., \& Fauzan, U. (2018). Analisis wacana kritis model Fairclough. The First Educational Linguistics Conference, 1(2), 524. https://doi.org/10.5296/ijl.v6i4.6147 